\title{
Performance and emission opacity of canola and soybean biodiesel fuel in a diesel engine
}

\author{
N.M. Taib ${ }^{1}$, M.S. Zainuddin ${ }^{1}$, M.R.A. Mansor $^{1 *}$, Z. Ilham ${ }^{2}$ \\ ${ }^{1}$ Department of Mechanical and Materials Engineering, Faculty of Engineering and \\ Built Environment, 43600 UKM Bangi, Selangor, Malaysia \\ *Email: radzi@ukm.edu.my \\ ${ }^{2}$ Institute of Biological Science, Faculty of Science, University of Malaya, \\ 50603 Kuala Lumpur, Malaysia
}

\begin{abstract}
Biodiesel is a renewable fuel known to produce more environmentally friendly emissions compared to diesel fuel. However, at times it has been reported as exhibiting a much lower engine performance compared to standard diesel fuel. Biodiesel fuel has the potential to achieve similar performance as compared to diesel fuel when the optimum percentage of biodiesel blend is used. In this study, an experiment was conducted to determine the performance and opacity of emissions collected from soybean biodiesel and canola biodiesel fuel by using a YANMAR TF90 single cylinder direct injection diesel engine. The objective of this study is to determine the best percentage of dieselsoybean and diesel-canola fuel mixture that would result in the best performance of an engine. The experiment investigated the brake specific fuel consumption (BSFC), brake thermal efficiency (BTE), brake power (BP), and torque generated by the engine using different biodiesel fuel percentages at varying engine speeds. Additionally, the emission opacity was investigated to identify the most favourable fuel percentage for optimised biodiesel compared to the quality obtained from soybean and canola soybean biodiesel. The results from the experiment clearly show that the engine using biodiesel fuel has a slightly lower performance as compared to the engine that only used diesel fuel for all percentages used. However, at low speeds, a BTE of $40 \%$ canola biodiesel was higher compared to diesel and soybean biodiesel. The BSFC for all biodiesel fuel was found to be slightly higher than diesel, except for BC40, which was greater for BSFC compared to other blends used at much lower engine speeds. Engine emission opacity of biodiesel was recorded to be less than diesel fuel at all engine speeds, but slightly higher for BC5, BS5 and BS20 due to the insufficient air intake to the engine. Engine performance and emission opacity of all biodiesel fuels were found to be similar to diesel fuel. From the results relating to engine performance and emission, canola biodiesel was found to be an excellent biodiesel product to be used in a diesel engine since it had a higher BTE, lower BSFC and a lower opacity which was greater than those of soybean biodiesel blends. Therefore, biodiesel can be blended in a diesel engine at a higher percentage while maintaining engine performance and reducing engine emission.
\end{abstract}

Keywords: Biodiesel; Performance; Opacity, Diesel Engine; Soybean; Canola. 


\section{INTRODUCTION}

The increasing demand for motor vehicles in the transportation sector, coupled with lower petroleum production, has created an increase in the motivation for many researchers to conduct studies into alternate renewable energy sources. Malaysia is recognised as being a strategic agricultural location, providing an advantage for producing alternate energy from renewable energy sources. Commencing in 2013, the amount of fuel consumption in Malaysia, led to an increase in the importation of crude oil. This information was also reported by the Malaysia Energy Commission, in their 2015 annual report [1]. To overcome this problem, Malaysia launched an initiative to increase the amount of biodiesel in diesel fuel by $7 \%$ and planning to increase this percentage even higher to $10 \%$ in 2017 . However, using $100 \%$ biodiesel or a higher percentage of biodiesel in diesel creates a problem which is currently being examined by a number of researchers globally. Due to this very issue, the implementation of B10 in Malaysia was put on hold in 2016 resulting from vehicle manufacturers refusing to allow their engines to use B10 due to the properties of biodiesel causing damage to the fuel injection and lubrication systems in the engine. However, the United States, on the other hand, has successfully implemented B20 in more than $95 \%$ of motor vehicles [2]. This achievement has brought together and motivated researchers in Malaysia to work towards optimising the highest biodiesel percentage that is compatible with diesel engines.

Biodiesel fuel is formed from several biological sources such as trees, plants or microorganisms. These sources are commonly known as carbon neutral sources where the fuel produces no net greenhouse emissions. Knowing when carbon dioxide would be emitted into the atmosphere from fuel would be useful in supporting new plant growth and aiding in photosynthesis from which fuel is produced [3]. In contrast to fossil fuels which contain carbon stored beneath the surface of the earth, when burnt, this increases the level of carbon dioxide in the atmosphere leading towards an imbalance in the photosynthesis process. Regular diesel fuel combustion released each year results in almost 35 million tonnes of $\mathrm{CO} 2$ emissions entering the atmosphere. Biodiesel fuel is recognised as being a suitable alternative fuel source to achieve the desired criteria because the $\mathrm{CO} 2$ can by reduced by $75 \%$ compared to diesel fuel [4].

The combustion of biodiesel fuel in engines will lead to a lower emission of smoke, particulate matter (PM), carbon monoxide (CO) and hydrocarbon (HC), and emit a much higher percentage of nitrogen oxide $\left(\mathrm{NO}_{\mathrm{x}}\right)$ [5][6][7]. Every year, the ratio of new biodiesel and diesel mixture is developed in Malaysia using different approaches and methods. Engine performance and emissions are used as the primary case study for identifying the best biodiesel-diesel blend. Studies from [8][9][10], highlight that biodiesel-diesel blended fuel produces lower $\mathrm{CO}$ and $\mathrm{CO} 2$ emissions, (about $32 \%$ of $\mathrm{CO}$ [11] and $21 \%$ of $\mathrm{CO}_{2}$ ) than diesel fuel for blending $\mathrm{B} 25$ to $\mathrm{B} 70$ [8]. However, the higher oxygen content found in biodiesel and high cylinder temperatures incurred during combustion caused higher NOx emissions for the diesel-ethanol blends [12][13].

The properties of biodiesel, namely kinematics viscosity, density and heating values are the most important parameters affecting the performance of the engine along with the characteristics of the emissions produced by the engine [14]. Other important performance parameters that influence the performance of the engine, such as the cetane number should be considered. The cetane number is a fuel quality indicator that affects the ignition timing. A higher cetane number can reduce the ignition delay period and start combustion shortly after being injected into the system [15]. Shorter ignition delay enables the fuel to burn off completely before the exhaust valve is opened and provides 
improved emission and performance [16][8]. Additionally, the density value has also been used to measure the amount of fuel in fuel systems using a volumetric method [14]. The variation of the density affect the viscosity of fuel and influence the fuel spray system and engine power during fuel injection and the combustion process in the cylinder chamber.

The emission of biodiesel and diesel contains a mixture of organic and inorganic complex compounds. The study on the biodiesel complex structure found that biodiesel or what is more commonly known as biofuels is dominated by an oxygenated species [17]. Organic compounds produced from sources such as unburned fuel and lubricating oil are partly generated during the combustion process or during the reaction of a catalyst [18]. The formation of unburned fuel that consists of soot, hydrocarbon and sulphate is formed as particulate matter. The impact of particulate matter formation leads to environment and human health problems [19][20].

Biodiesel has the high potential to reduce the problem of $\mathrm{CO}_{2}$ emissions by partially meeting the requirements of fuel requirements, especially in rural areas[21]. Biodiesel provides an efficient alternative for the future of diesel fuel where the emissions from biodiesel are much lower, if not similar to diesel fuel. The use of biodiesel blended fuel in a diesel engine has a positive impact on the combustion parameters in the diesel engine [22]. However, the combustion of biodiesel fuel may affect engine performance on the BSFC as it can also lead to a higher BSFC because of the increased energy content contained within biodiesel. This is due to biodiesel having a higher density which affects the BSFC and increases fuel consumption while slightly reducing its overall performance [23]. External research and studies have been conducted relating to the improvement of engine performance and emissions using biodiesel and their blends [24][25][26]. Biodiesel fuel has the characteristics of having high thermal efficiency, meaning that the combustion process of the fuel is improved and more complete. The production of unburned hydrocarbons is lower, leading to a lower opacity of the emissions generated by biodiesel compared to diesel fuel [27]. Diesel fuel has a higher calorific value than biodiesel fuel. However, the concentration and density of diesel fuel are both lower [25].

Biodiesel is a fuel produced from oil or fatty acid that has undergone a chemical reaction process called transesterification [28], and where alcohol and natrium hydroxide are used as a transesterification additive [29]. In research undertaken, cooking oil is recognised as being the primary source used in biodiesel production because it is easily acquired, especially those made from palm oil, jatropha, soybean and canola. Therefore, the objective of this study is to produce a mixture of biodiesel and diesel fuel that is ideal for optimum performance while having a low opacity of exhaust emissions. For this study, biodiesel produced from soybean and canola is considered suitable to perform the experiment. The best engine performance using the biodiesel diesel blend was selected as the preferred mixture. In addition, the performance between soybean biodiesel and canola biodiesel was compared.

\section{EXPERIMENTAL SETUP}

\section{Fuel composition preparation}

For the experiment, soybean and canola cooking oils were used and purchased from a local market in Malaysia. Both oils were prepared separately, heated up to $50{ }^{\circ} \mathrm{C}$ before mixing the oils into methanol using Sodium hydroxide as a catalyst for the transesterification process, refer Figure 1. Transesterification is a process to eliminate glycerol from triglyceride and produces methyl ester [30]. The process was conducted 
over a 48-hour period with continuous stirring every 30 seconds. Once the biodiesel was prepared for both types, each type of biodiesel blend was labelled as BS for soybean biodiesel and BC for canola biodiesel. The following percentages of canola and soybean biodiesel were used to mix with diesel fuel; 5\%, 20\% and 40\% respectively. The acronyms were numbered to represent the percentage of biodiesel blend; BS5, BS20, BS40, BC5, BC20 and BC40 as shown in Table 1.

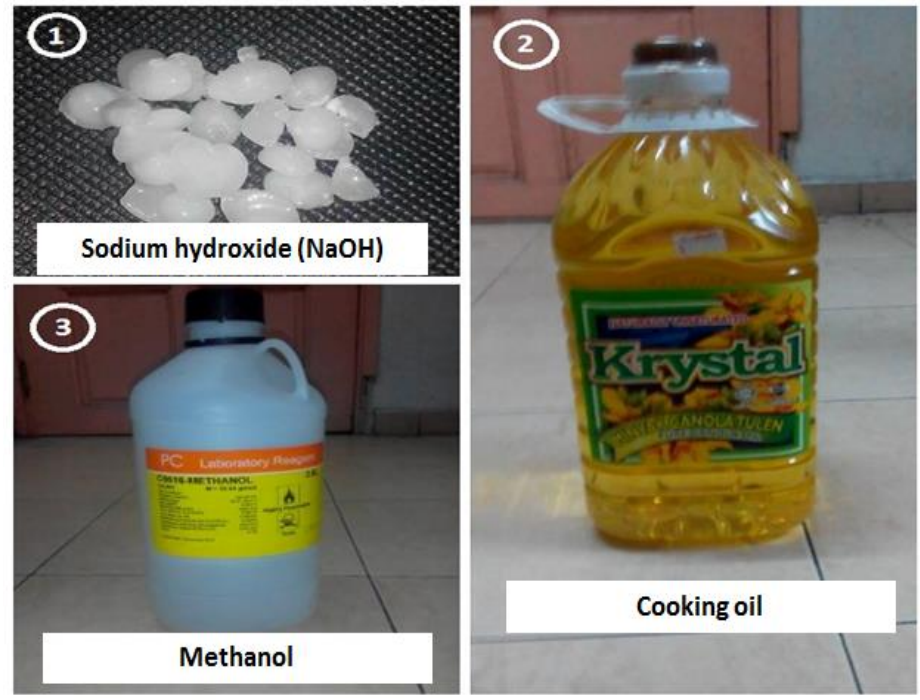

Figure 1. Biodiesel preparation

Table 1. The percentage of the blend for biodiesel and diesel.

\begin{tabular}{ll}
\hline Percentage of blend & Acronyms \\
\hline Soybean biodiesel 5\% + Diesel 95\% & BS5 \\
Soybean biodiesel 20\% + Diesel 80\% & BS20 \\
Soybean biodiesel 40\% + Diesel 60\% & BS40 \\
Canola biodiesel 5\% + Diesel 95\% & BC5 \\
Canola biodiesel 20\% + Diesel 80\% & BC20 \\
Canola biodiesel 40\% + Diesel 60\% & BC40 \\
\hline
\end{tabular}

\section{Experimental Procedure}

Performance and the opacity of emissions were the main parameters of focus in the study. The performance and emissions were measured using a YANMAR TF90 single cylinder direct injection diesel engine, as illustrated in Figure 2. Engine torque and exhaust emissions were measured using a gas analyser and dynamometer connected to the exhaust pipe and engine shaft. In this experiment, an eddy current LENZE dynamometer was connected directly to the engine. The torque, engine speed, load, temperature, current and voltage output reading were collected from the dynamometer control board. Exhaust emission analysis was another important area of analysis in measuring fuel optimisation. A BOSCH gas analyser was used to extract the gas from the exhaust pipe to study the exhaust emissions of $\mathrm{CO}, \mathrm{CO}_{2}, \mathrm{HC}$ and soot.

Fuel was stored in a fuel flowmeter up to $80 \mathrm{ml}$ with the time recorded for each $10 \mathrm{ml}$ of fuel reduction to calculate the fuel consumption. During the experiment, the torque reading was recorded and displayed on the control board for different speeds, at different loads, and with increments of $200 \mathrm{rpm}$ within the range of $1200 \mathrm{rpm}$ and 2000 
rpm. Furthermore, the load was adjusted for zero load, $2 \mathrm{~kW}$, and $4 \mathrm{~kW}$. The maximum load used for the engine was $4 \mathrm{~kW}$ because of the engine's very low speed and power capability. If the load achieved was higher than $4 \mathrm{~kW}$, the maximum speed achieved would be less than $2000 \mathrm{rpm}$.

The YANMAR TF90 engine can produce $6.3 \mathrm{~kW}$ power output and operates up to $2400 \mathrm{rpm}$ as presented in the engine specification, Table 2.

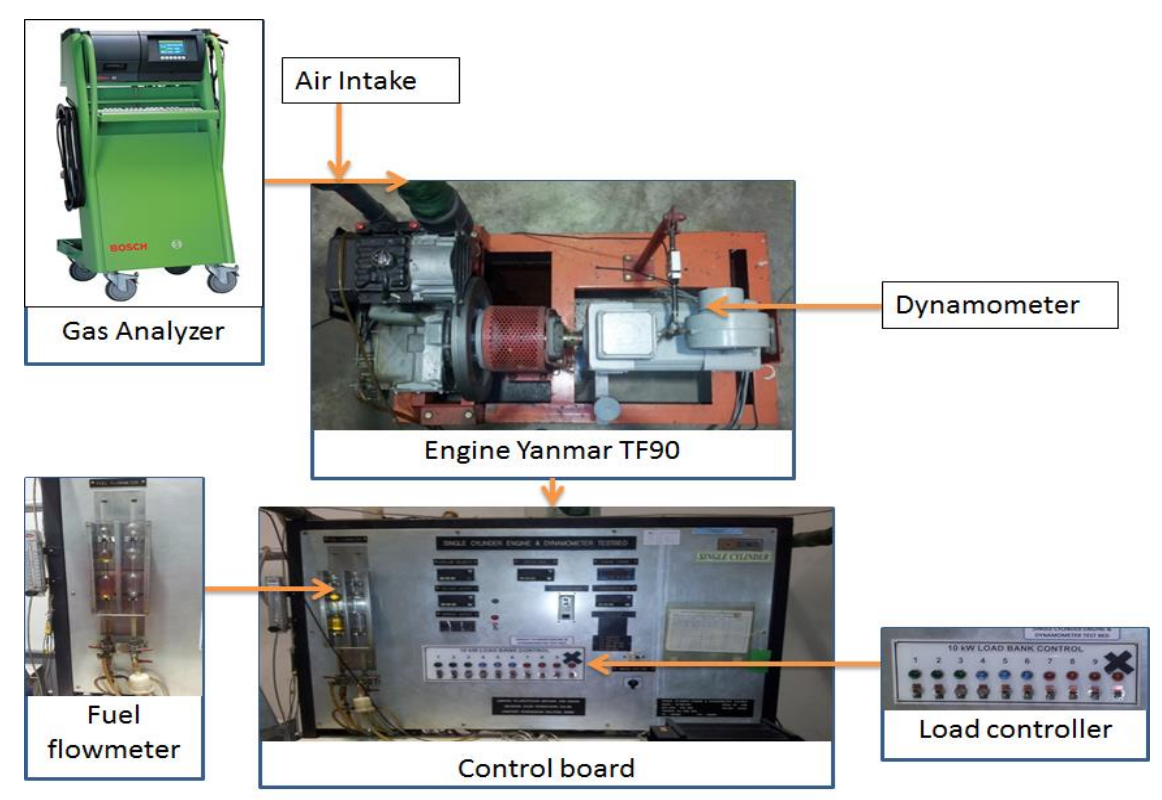

Figure 2. Engine and measuring equipment diagram of the experiment.

Table 2. Specification of the engine.

\begin{tabular}{ll}
\hline Details & Specification \\
\hline Model & YANMAR TF90 \\
Number of cylinders & 1 \\
Total volume (litre) & 0.493 \\
Compression ratio & 18.0 \\
Cylinder Bore x Stroke $(\mathrm{mm})$ & $85 \times 87$ \\
Continuous Rated Output, hp/rpm $(\mathrm{kW})$ & $8.5 / 2400(6.3)$ \\
Type of fuel & Diesel \\
Cooling system & Hopper $(\mathrm{H})$ \\
Capacity of cooling system (litre) & $8.0(\mathrm{H})$ \\
\hline
\end{tabular}

The engine analysis examined the brake thermal efficiency (BTE), brake specific fuel consumption (BSFC), brake power and the emission of exhaust gas. BTE is obtained from the brake power, $b p$ and mass flow rate, $\dot{\mathrm{m}}_{f}$ of fuel relation, as shown in Equation (1) where brake power, $b p$ is calculated from the relationship of torque and engine revolution.

$$
B S F C=\frac{\text { fuel mass flow rate, } \dot{\mathrm{m}}_{f}}{\text { brake power, } b p}\left[\frac{k g}{k W h}\right]
$$




\section{RESULTS AND DISCUSSION}

Figure 3 illustrates the brake power produced by the engine when using diesel, soybean biodiesel and canola biodiesel fuel having a maximum load of $4 \mathrm{~kW}$ applied to the YANMAR TF90 diesel engine. The engine speed was limited to $2000 \mathrm{rpm}$ for the safety and limitation of cooling system conditions. The highest brake power of $2.137 \mathrm{~kW}$ was achieved using diesel fuel at $2000 \mathrm{rpm}$ followed by $2.015 \mathrm{~kW}$ produced by biodiesel BS5. This demonstrated that the brake power decreased by about $1.4 \%$ when using soybean biodiesel fuel at a 5\% mixture ratio. Meanwhile, biodiesel BC5 gives $2.095 \mathrm{~kW}$ of brake power where the brake power was shown to decrease by approximately $1.96 \%$ at the highest engine speed.

The brake power for both biodiesel formed from canola and soybean was much lower as compared to diesel, which has the highest brake power at $2000 \mathrm{rpm}$. This is because a lower percentage of biodiesel may contain less oxygen content resulting in lower brake power compared to the higher percentage of biodiesel. This is further as evidenced by the research conducted by T.K. Gogoi, where he identified $40 \%$ and $60 \%$ of biodiesel as having a higher brake power, and $20 \%$ biodiesel having a much lower brake power than that of diesel fuel. Another reason for the reduction in brake power is because biodiesel has a higher calorific value than the value for diesel fuel. The result is causing the combustion energy to be lower, resulting in reduced brake power [31]. Brake power is typically reported as decreasing after reaching a speed of $3000 \mathrm{rpm}$, resulting from the engine working too fast with frictional loss occurring [25]. The results from the experiment also highlighted that a brake power of $5 \%$ biodiesel fuel blend, is similar to diesel fuel. This confirms that $5 \%$ of biodiesel can be used in a diesel engine with small differences in brake power. From the studies and results presented by M.J. Abedin et al,, brake power of biodiesel is seen to be closer to diesel fuel at lower speeds but slightly increasing when engine speed increases [25].

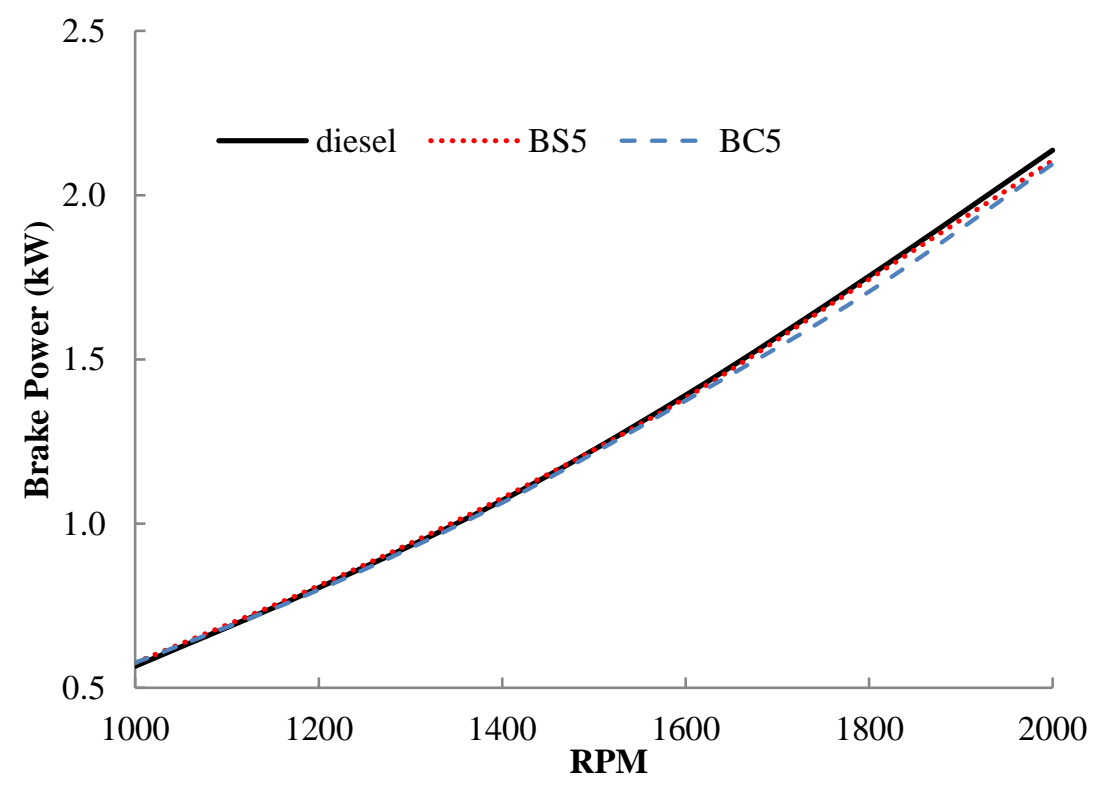

Figure 3. Brake power for 5\% soybean, canola and diesel fuel.

The graph in Figure 4 illustrates the results of BSFC produced by the engine with a $2 \mathrm{~kW}$ load when using soybean biodiesel, canola biodiesel and diesel fuel. The BSFC of the engine using diesel fuel at a maximum speed was $0.324 \mathrm{~kg} / \mathrm{kWh}$. The BSFC for 
soybean biodiesel BS5 was $0.338 \mathrm{~kg} / \mathrm{kWh}$ which is $4.34 \%$ higher than diesel fuel. BS20 also displayed a higher BSFC difference of $7.08 \%$ compared to diesel fuel at $0.346 \mathrm{~kW}$. The BSFC for biodiesel BS40 was recorded at $0.352 \mathrm{~kg} / \mathrm{kWh}$, which is $8.71 \%$ higher than diesel fuel and was recorded as being the highest BSFC among all blends. This trend shows the value of BSFC increasing with the increase of biodiesel and greater as compared to diesel fuel. The studies by M.J. Abedin, 2014, concluded that where $20 \%$ jatropha and palm oil biodiesel provided a higher BSFC, this was primarily due to having a higher density, viscosity and a lower heating value [25]. Higher density and viscosity of biodiesel leads to a much larger droplet size and leads to a weaker atomisation process during combustion[14]. Besides, biodiesel has a lower heating value that results in a higher BSFC [11].

BSFC produced by the engine when using canola biodiesel is $0.323 \mathrm{~kg} / \mathrm{kWh}$ for BC5 at its highest engine speed, which is $0.14 \%$ lower than that of diesel fuel. On average, all canola biodiesel fuels have a much higher BSFC as compared to diesel fuel. BC5 was recorded as having the lowest BSFC, with BC40 recorded as having the highest BSFC of around $6.42 \%$ higher than diesel fuel. At lower speeds, BSFC of BS40 was recorded as being $13.35 \%$ higher than diesel fuel, and greater than BC40. This is because of the kinematic viscosity factor associated with the fuel. A large percentage of biodiesel increases the viscosity of fuel and causes the mixture of fuel and air to become much weaker and therefore increasing the BSFC [32]. From the results obtained using soybean biodiesel, this shows a higher BSFC than canola biodiesel for a given higher percentage.

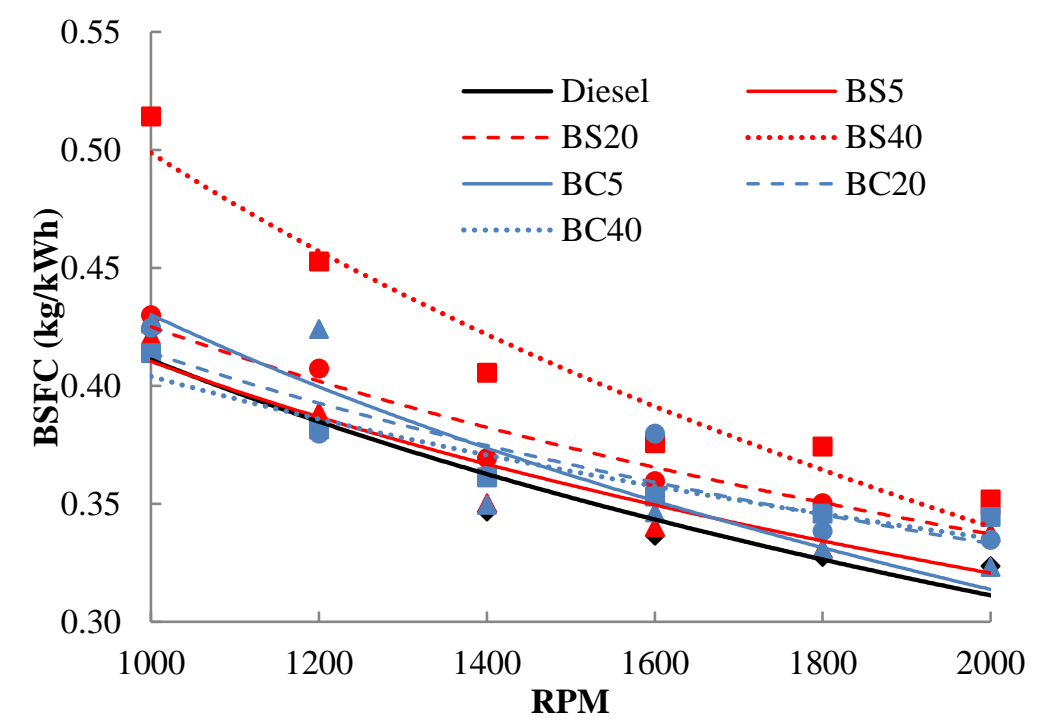

Figure 4. BSFC of soybean biodiesel, canola biodiesel and diesel.

Brake thermal efficiency (BTE) is a parameter that measures the ability of the engine to convert energy from combustion fuel into mechanical energy to operate the engine. Figure 5, shows the brake thermal efficiency of soybean biodiesel, canola biodiesel and diesel at the same loads of $2 \mathrm{~kW}$ being applied at various engine speeds. The lower BTE shows that the efficiency of the engine to convert the energy from fuel to produce brake power is low. This is due to biodiesel having a lower heating value than that of diesel fuel, and since fuel energy is proportional to the heating value, the thermal efficiency is also lower than diesel fuel [28]. Figure 6, shows BTE increasing with increased engine speed and the highest engine speed with $24.5 \%$ for diesel fuel, $24.1 \%$ for $\mathrm{BS} 5,23.0 \%$ for $\mathrm{BS} 20$ and $24.1 \%$ for BS40. 
Meanwhile, the BTE for BC5 recorded $24.98 \%$, BC20 of $24.6 \%$ and $24.4 \%$ for BC40 biodiesel fuel. From the graph, it clearly shows the combustion of biodiesel in an internal combustion engine giving a lower BTE compared to diesel. The graph also shows the BTE for canola biodiesel blends being higher than soybean biodiesel blends. This is because canola may contain a higher oxygen content than soybean biodiesel [28], and that canola biodiesel is better than soybean biodiesel when operating at lower engine speeds. Having a higher density of biodiesel will lead to having a lower BTE because the higher viscosity of fuel can cause poor atomisation of fuel droplets during combustion, and cause the evaporation of fuel to be much slower so that the combustion requires more time and reduces the thermal efficiency [33][22].

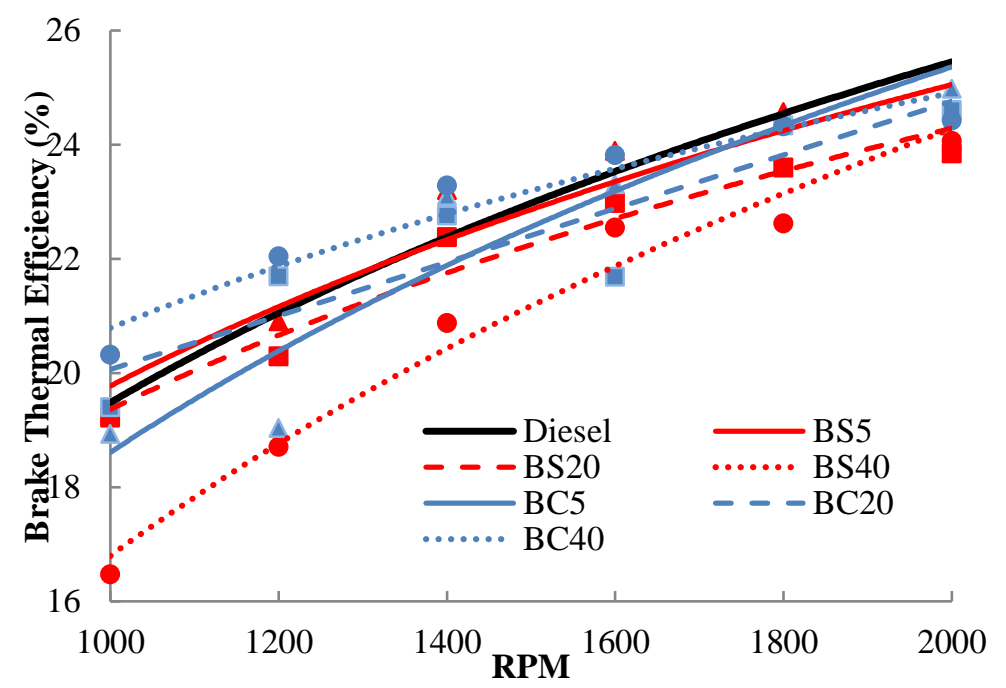

Figure 5. BTE for canola biodiesel, soybean biodiesel and diesel.

\section{Opacity of emissions}

Figure 6, shows the opacity of the exhaust emissions for soybean biodiesel and diesel produced by the engine. The highest opacity recorded in the graph is for diesel fuel as compared to biodiesel fuel. The largest opacity of fuel is registered at $1000 \mathrm{rpm}$ for all fuels and continuously decreases until the engine speed reaches $1600 \mathrm{rpm}$. The opacity increased at $2000 \mathrm{rpm}$ compared to $1600 \mathrm{rpm}$ for all type of blended fuel. Both soybean and canola biodiesel produce lower opacity than diesel fuel. This is because biodiesel has a higher oxygen content leading to much leaner combustion [34]. Therefore, increasing the percentage of biodiesel results in a lower emission opacity. Biodiesel BS5 gave $2.9 \%$ opacity at $1000 \mathrm{rpm}$ and decreased to $0.85 \%$ at $1600 \mathrm{rpm}$. The opacity was increased again at 1800 and $2000 \mathrm{rpm}$ respectively, with percentage of $1.33 \%$ and $1.85 \%$ exceeding the smoke opacity of diesel at $2000 \mathrm{rpm}$. This is primarily due to the insufficient intake of air into the cylinder when the piston moves too fast and BS5 containing the lowest oxygen content as compared to BS20 and BS40. Canola biodiesel produced a similar graph pattern to that of soybean biodiesel where at $2000 \mathrm{rpm}$, the opacity of BC5 was higher than diesel fuel.

When the engine was operated at a higher speed, the rapid opening of the intake valve allowed insufficient air for combustion to occur and led towards having higher opacity. BC20 was recorded as having higher opacity than diesel fuel at $2000 \mathrm{rpm}$ while BS20 maintained a lower opacity than diesel fuel. This demonstrates that canola biodiesel contains lower oxygen content with a higher carbon content in the fatty acid chain than soybean. At a higher speed, canola biodiesel has insufficient oxygen, increasing emission 
opacity [10]. So, using $40 \%$ biodiesel in diesel fuel is appropriate since the opacity of biodiesel blends up to $40 \%$ and able to reduce emission opacity $0.5 \%$ lower than diesel fuel.

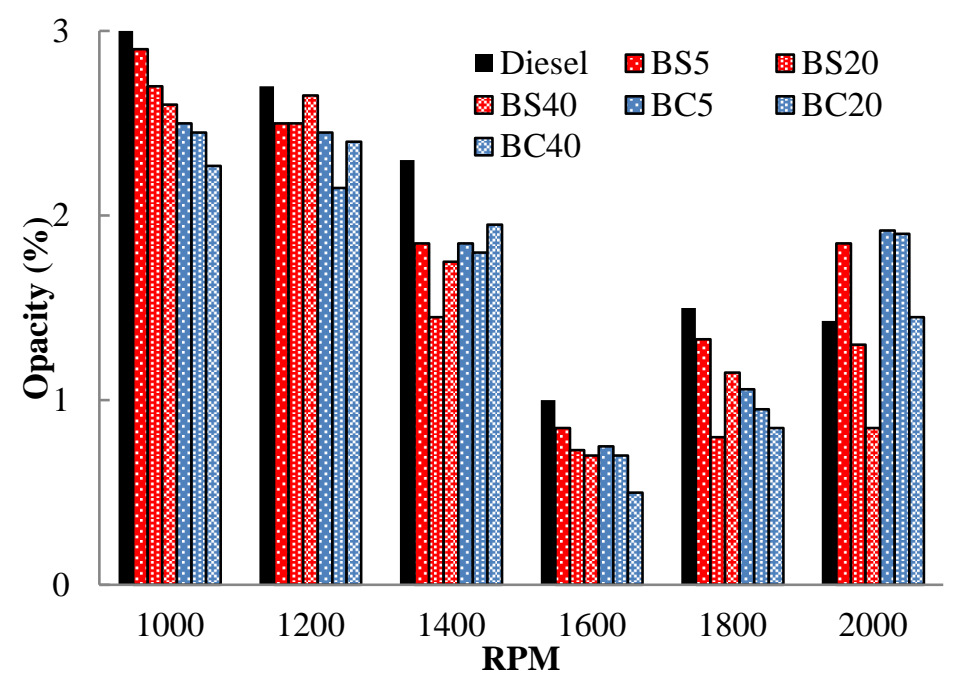

Figure 6. The emission opacity for soybean biodiesel, canola biodiesel and diesel.

\section{CONCLUSIONS}

Canola and soybean biodiesel has the potential to replace diesel fuel in a diesel engine because biodiesel is a biofuel product able to reduce the problems associated with emissions found in a diesel engine. The study on engine performance and the emission of biodiesel in diesel blends indicated a positive result with 5\%,20\% and $40 \%$ of biodiesel in diesel showing promising results in BTE, BSFC and exhaust smoke opacity. The brake thermal efficiency of biodiesel is slightly lower than diesel, and 5\% and $20 \%$ biodiesel showed to have the closest thermal efficiency for an engine. The percentage difference between diesel and $40 \%$ of biodiesel is small when operating at higher engine speeds and larger at lower speeds.

At low speeds, canola biodiesel has a higher BTE than diesel fuel, confirming that canola biodiesel performs better having a low operational engine load. The BSFC of canola and soybean biodiesel recorded lower results than diesel fuel. However, soybean biodiesel was found to have a higher BSFC compared to canola biodiesel at low engine speeds. Therefore, canola biodiesel exhibits better engine performance compared to soybean biodiesel. In exhaust emission opacity, all biodiesel percentages had lower opacity compared to diesel fuel with $0.5 \%$ on average being lower than diesel fuel. However, at $2000 \mathrm{rpm}$, the emission opacity of BS5, BC5 and BC20 was only $0.5 \%$ higher than diesel fuel. This is due to the insufficient intake of air for combustion. In the future, the implementation of a higher percentage of biodiesel should be optimised with minimal engine modification and having noticeably improved engine emissions being less harmful to the environment.

\section{REFERENCES}

[1] Energy Commission, "Malaysia Energy Statistics Handbook 2015,” 2015.

[2] Wahab AG. Malaysia Biofuels Annual. USDA Foreign Agricultural Service GAIN Report, 2013; pp. 1-10. 
[3] An L, Zhao TS, Li YS. Carbon-neutral sustainable energy technology: Direct ethanol fuel cells. Renewable Sustainable Energy Review. 2015; 50:1462-1468.

[4] Freitas SVD, Oliveira MB, Queimada AJ, Pratas MJ, Lima AS, Coutinho JAP. Measurement and prediction of biodiesel surface tensions. Energy and Fuels. 2011; 25: 4811-4817.

[5] Aydin H, İlkılıç C. Effect of ethanol blending with biodiesel on engine performance and exhaust emissions in a CI engine. Applied Thermal Engineering. 2010; 30:1199-1204.

[6] Tat M, Van Gerpen J. The specific gravity of biodiesel and its blends with diesel fuel. Journal of the American Oil Chemists' Society. 2000;77:115-119.

[7] Nabi MN, Rahman MM, Akhter MS. Biodiesel from cotton seed oil and its effect on engine performance and exhaust emissions. Applied Thermal Engineering. 2009; 29: 2265-2270.

[8] Sharon H, Karuppasamy K, Soban Kumar DR, Sundaresan A. A test on DI diesel engine fueled with methyl esters of used palm oil. Renewable Energy. 2012; 47: 160-166.

[9] Hulwan DB, Joshi SV. Performance, emission and combustion characteristic of a multicylinder DI diesel engine running on diesel-ethanol-biodiesel blends of high ethanol content. Applied Energy. 2011; 88:5042-5055.

[10] Ong HC, Masjuki HH, Mahlia TMI, Silitonga AS, Chong WT, Yusaf T. Engine performance and emissions using Jatropha curcas, Ceiba pentandra and Calophyllum inophyllum biodiesel in a CI diesel engine. Energy. 2014; 69: 427445.

[11] Celikten I. The Effect of Biodiesel, Ethanol and Diesel Fuel Blends on The Performance and Exhaust Emissions in A DI Diesel Engine. Gazi University Journal of Science. 2011; 24: 341-346.

[12] Kiat H, Gan S, Ng JH, Mun K, Ng HK, Gan S, Ng JH, Pang KM. Simulation of biodiesel combustion in a light-duty diesel engine using integrated compact biodiesel - diesel reaction mechanism. Applied Energy. 2013; 102:1275-1287.

[13] Taib NM, Mansor MRA, Mahmood WMFW, Shah FA, Abdullah NRN. Investigation of diesel-ethanol blended fuel properties with palm methyl ester as co-solvent and blends enhancer. MATEC Web of Conference. 2016; 90.

[14] Alptekin E, Canakci M. Determination of the density and the viscosities of biodiesel-diesel fuel blends. Renewable Energy. 2008; 33:2623-2630.

[15] İçıngür Y, Altiparmak D. Effect of fuel cetane number and injection pressure on a DI Diesel engine performance and emissions. Energy Conversion Management. 2003; 44:389-397.

[16] Shahabuddin M, Liaquat AM, Masjuki HH, Kalam MA, Mofijur M. Ignition delay, combustion and emission characteristics of diesel engine fueled with biodiesel. Renewable and Sustainanle Energy Review. 2013; 21:623-632.

[17] Ahmad R, Hamidin N, Ali UFM, Abidin CZA. Characterization of Bio-Oil From Palm Kernel Shell Pyrolysis. Journal of Mechanical Engineering and Sciences. 2014; 7:2289-4659.

[18] Agarwal AK, Gupta T, Kothari A. Particulate emissions from biodiesel vs diesel fuelled compression ignition engine. Renewable and Sustainable Energy Review. 2011; 15:3278-3300.

[19] Ibrahim F, Mahmood WMFW, Abdullah S, Mansor MRA. Soot Particle Measurement in Engine Cylinder : A Review. Jurnal Teknologi. 2016; 8:187-195.

[20] Ibrahim F, Mahmood WMFW, Abdullah S, Mansor MRA. A Review of Soot 
Particle Measurement in Lubricating Oil. Defence S\&T Techinal Bulletin. 2015; $8: 141-152$.

[21] Cherubini F, Bird ND, Cowie A, Jungmeier G, Schlamadinger B, Woess-Gallasch S. Energy- and greenhouse gas-based LCA of biofuel and bioenergy systems: Key issues, ranges and recommendations. Resources, Conservation and Recycling. 2009; 53:434-447.

[22] Yasin MHM, Mamat R, Aziz A, Yusof AF, Ali MH. Investigation on Combustion Parameters of Palm Biodiesal Operating with a Diesel Engine. Journal of Mechanical Engineering and Sciences. 2015; 9:1714-1726.

[23] Monyem A, Van Gerpen JH. The effect of biodiesel oxidation on engine performance and emissions. Biomass and Bioenergy. 2001;20:317-325.

[24] Atabani AE, Silitonga AS, Ong HC, Mahlia TMI, Masjuki HH, Badruddin IA, Fayaz H. Non-edible vegetable oils: A critical evaluation of oil extraction, fatty acid compositions, biodiesel production, characteristics, engine performance and emissions production. Renewable and Sustainable Energy Review. 2013; 18:211245.

[25] Abedin MJ, Masjuki HH, Kalam MA, Sanjid A, Rahman SMA, Fattah IMR. Performance, emissions, and heat losses of palm and jatropha biodiesel blends in a diesel engine. Industrial Crops and Products. 2014; 59:96-104.

[26] Ali OM, Mamat R, Abdullah NR, Abdullah AA. Analysis of blended fuel properties and engine performance with palm biodiesel-diesel blended fuel. Renewable Energy. 2015; 86:59-67.

[27] Buyukkaya E. Effects of biodiesel on a DI diesel engine performance, emission and combustion characteristics. Fuel. 2010; 89:3099-3105.

[28] Bhaskar K, Sendivelan S, Muthu V, Aravindraj S. Performance and emission characteristics of compression ignition engine using methyl ester blends of jatropha and fish oil. Journal of Mechanical Engineering and Sciences. 2016;10:1994-2007, 2016.

[29] Redzwan G, Amin MM, Zulkarnain NN, Mansor MRA, Annuar MSM, Ilham Z. Extrication of biodiesel feedstock from early stage of food waste liquefaction. Journal of Material Cycles and Waste Management. 2017;19:676-681.

[30] Habibullah M, Masjuki HH, Kalam MA, Rizwanul Fattah IM, Ashraful AM, Mobarak HM. Biodiesel production and performance evaluation of coconut, palm and their combined blend with diesel in a single-cylinder diesel engine. Energy Conversion and Management. 2014; 87:250-257.

[31] Gogoi TK, Baruah DC. A cycle simulation model for predicting the performance of a diesel engine fuelled by diesel and biodiesel blends. Energy. 2010; 35:13171323.

[32] Ganapathy T, Gakkhar RP, Murugesan K. Influence of injection timing on performance, combustion and emission characteristics of Jatropha biodiesel engine. Applied Energy. 2011; 88:4376-4386.

[33] Yoon SH, Park SH, Suh HK, Lee LS. Effect of Biodiesel-Ethanol Blended Fuel Spray Characteristics on the Reduction of Exhaust Emissions in a Common-Rail Diesel Engine. Journal of Energy Resources and Technology. 2010;132:1-7.

[34] Mofijur M, Rasul MG, Hyde J, Azad AK, Mamat R, Bhuiya MMK. Role of biofuel and their binary (diesel-biodiesel) and ternary (ethanol-biodiesel-diesel) blends on internal combustion engines emission reduction. Renewable and Sustainable Energy Review. 2016;53:265-278. 